\title{
Social and obstetric factors associated with the way of delivery: reality of a maternity school in the interior of the northeast
}

\author{
Fatores sociais e obstétricos associados à via de parto: realidade de uma maternidade escola no \\ interior do nordeste
}

Factores sociales y obstétricos associados a la forma de entrega realidade de uma escuela de maternidade en el interior del noreste

Received: 07/21/2021 | Reviewed: 07/26/2021 | Accept: 07/28/2021 | Published: 08/04/2021

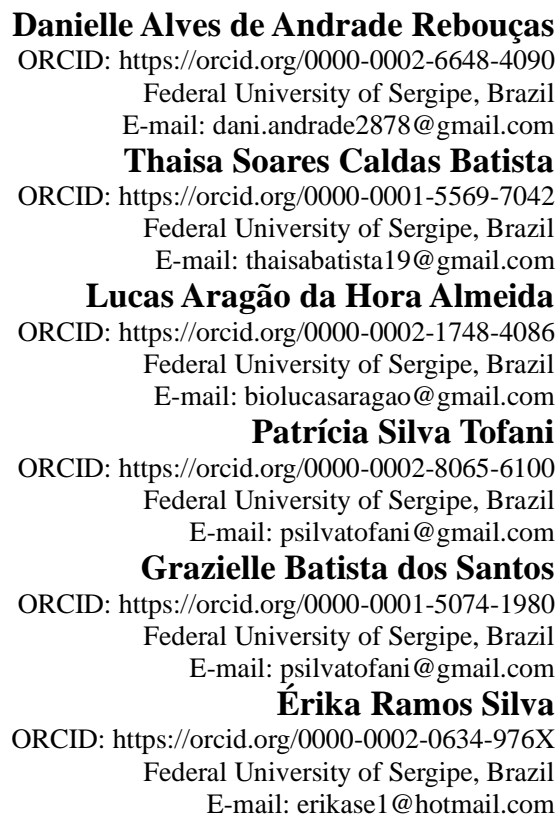

\begin{abstract}
The study aims to identify the social and obstetric factors associated with the mode of delivery of postpartum women attending a public maternity hospital located in the interior of the state of Sergipe, in the northeast region. This is a cross-sectional study that included 1,149 postpartum women in the immediate period, carried out between November 2016 and December 2019, who underwent functional kinesiological assessment for physical therapy care. Descriptive analysis and binary logistic regression were performed using the mode of delivery as the dependent variable. The results showed that the prevalence of cesarean deliveries was of $49.24 \%(n=565)$. Most puerperal women were young, married, primiparous and with elementary education. Vaginal delivery was associated with postpartum women with married marital status (OR, 10.463; 95\%CI, 2.367-46.254), multipregnancy (OR, 9.54; 95\% CI, 7.19-12.65), multiparous (OR, 8.79; 95\%CI, 6.66-11.62), with no pain (OR, 2.08; 95\%CI, 1.63-2.65), no comorbidities (OR,1.69, 95\%CI, 1.23-2.28), number of prenatal consultations from one to seven (OR, 1.534; 95\%CI, 1.18-1.98), and without difficulty to breastfeed (OR, 1.373, 95\%CI, 1.04-1.80). The cesarean delivery route was associated with abortion in primiparae (OR, 1.69; 95\%CI, 1.192-2.415) and education at the elementary level. (OR, 2.99; 95\%CI, 1.403-6.411). It is concluded that social factors (education level and marital status), obstetric factors (parity, number of pregnancies, comorbidities, obstetric care) and immediate puerperal complaints (pain and difficulty in breastfeeding) were associated with the modes of delivery.
\end{abstract}

Keywords: Postpartum period; Women's health; Cesarean section; Social determinants of health.

\section{Resumo}

O estudo objetiva identificar os fatores sociais e obstétricos associados à via de parto de puérperas atendidas numa maternidade pública localizada no interior do estado de Sergipe, região nordeste. Estudo transversal que incluiu 1.149 puérperas no período imediato realizado entre novembro de 2016 e dezembro de 2019, submetidas à avaliação cinesiológica funcional para atendimento fisioterapêutico. A análise descritiva e a regressão logística binária foram 
realizadas utilizando a via de parto como variável dependente. Os resultados mostraram que a prevalência de partos por via cesárea foi de $49.24 \%(\mathrm{n}=565)$. A maioria das puérperas eram jovens, casadas, primíparas e com escolaridade fundamental. A via de parto vaginal esteve associada às puérperas com estado civil casada (OR, 10.463; 95\%CI, 2.367-46.254), multigestas (OR, 9.54; 95\% CI, 7.19-12.65), multíparas (OR, 8.79; 95\%CI, 6.66-11.62), com ausência de dor (OR, 2.08; 95\%CI, 1.63-2.65), sem comorbidades (OR,1.69, 95\%CI, 1.23-2.28), número de consultas prénatais de uma a sete (OR, 1.534; 95\%CI, 1.18-1.98, e sem dificuldade para amamentar (OR, 1.373, 95\%CI, 1.041.80). A via de parto cesárea apresentou associação com aborto em primíparas (OR, 1.69; 95\%CI, 1.192-2.415) e a escolaridade em nível fundamental (OR, 2.99; 95\%CI, 1.403-6.411). Conclui-se que os fatores sociais (nível de escolaridade e estado marital), obstétricos (paridade, número de gestações, comorbidades, acompanhamento obstétrico) e as queixas puerperais imediatas (dor e dificuldade de amamentar) estiveram associados às vias de parto. A eficácia da educação e saúde, bem como a intervenção interdisciplinar baseadas em evidências científicas podem contribuir para a condução da gestação e parto, repercutindo em melhor estado puerperal imediato.

Palavras-chave: Período pós-parto; Saúde da mulher; Cesárea; Determinantes sociais da saúde.

\section{Resumen}

El estudio tiene como objetivo identificar los factores sociales y obstétricos asociados al modo de parto de las madres que acuden a maternidad pública ubicada en el interior del estado de Sergipe, región noreste. Estudio transversal que incluyó a 1.149 puérperas en el período inmediato, realizado entre noviembre de 2016 y diciembre de 2019, a las que se les realizó valoración kinesiológica funcional para la atención de fisioterapia. El análisis descriptivo y la regresión logística binaria se realizaron utilizando el modo de parto como variable dependiente. Los resultados mostraron que la prevalencia de partos por cesárea fue del 49,24\% $(\mathrm{n}=565)$. La mayoría de las puérperas eran jóvenes, casadas, primíparas y con educación básica. La vía de parto vaginal se asoció con mujeres posparto con estado civil casadas (OR, 10.463; 95\%CI, 2.367-46.254), multigesta (OR, 9.54; 95\% CI, 7.19-12.65), multípara (OR, 8.79; 95\%CI, 6.6611.62), sin dolor (OR, 2.08; 95\%CI, 1.63-2.65), sin comorbilidades (OR,1.69, 95\%CI, 1.23-2.28), número de consultas prenatales de una a siete (OR, 1.534; 95\%CI, 1.18-1.98) y sin dificultad para amamentar (OR, 1.373, 95\%CI, 1.04-1.80). La vía de parto por cesárea se asoció con el aborto en primíparas (OR, 1.69; 95\%CI, 1.192-2.415) y educación a nivel elemental (OR, 2.99; 95\%CI, 1.403-6.411). Se concluye que factores sociales (nivel de educación y estado civil), factores obstétricos (paridad, número de embarazos, comorbilidades, seguimiento obstétrico) y quejas puerperales inmediatas (dolor y dificultad en la lactancia) se asociaron con las formas de parto. La efectividad de la educación y la salud, así como la intervención interdisciplinaria basada en evidencia científica, pueden contribuir al manejo del embarazo y parto, resultando en un mejor estado puerperal inmediato.

Palabras clave: Periodo posparto; Salud de la mujer; Cesárea; Determinantes sociales de la salud.

\section{Introduction}

Maternal and child mortality reflects the effectiveness of health care for women and children and includes the quality of women's health care in the cycle of pregnancy, childbirth and the puerperium. This concern increases when considering that $26.4 \%$ of women had no prenatal care or had it inadequately or incompletely; $55.7 \%$ of births were by cesarean section and the prematurity rate is still higher than $10 \%$ of births (MS, 2019). The mode of delivery is associated with sociodemographic, cultural and economic factors, medical and maternal issues (Moreira et al., 2016), obstetric characteristics, available technological and human resources and care protocols (Lofti et al., 2014).

The health services, for the most part, are not prepared to care for puerperal women because the referral and counterreferral systems are not effective in monitoring the multiple factors that interfere in the obstetric history (Andrade et al., 2015). Reduction in the number and quality of postpartum consultations associated with fragmented, biological and newborn-focused care (Baratieri \& Natal, 2019) reveal a lack of comprehensive care as it does not include the sociocultural and family contex ts. In addition, discontinuation of care can result in greater vulnerability with high rates of maternal morbidity and mortality until the late postpartum period (11th to 45th day postpartum), especially in the Northeast region of Brazil (MS, 2011).

The puerperal period was only included for primary care assistance after the creation of the Integrated Assistance Program for Women's Health (PAISM) in 1984 (Andrade et al., 2015). This period combines the exercise of motherhood with the local and systemic physiological involutions characteristic of the pregnancy period. The choice of the mode of delivery and the care offered in the immediate postpartum period can interfere with the emergence of problems to maternal health, such as pain, discomfort or other outcomes, which impact the mobility and functionality of this phase (Pereira et al., 2017). In this 
sense, interdisciplinary care, including physical therapy, is a facilitator for the rapid return to the pre-pregnancy state, by preventing complications, reducing pain and promoting the general well-being of the postpartum woman (Burti et al., 2016).

Although several studies have evaluated the social and obstetric factors associated with the mode of delivery, the methodology applied differs in terms of parity, previous history of cesarean section and, especially, the disparity between the preferred mode of delivery and the actual mode of delivery (Mazzoni et al., 2019). Knowing the profile of postpartum women in each location is essential for the creation of public policies, development of strategies aimed at comprehensive care for women and implementation of humanized care protocols that address the biopsychosocial and functional aspects during pregnancy, childbirth and the puerperium. Based on these indicators, this study aimed to identify the profile of immediate postpartum women considering the mode of delivery and the social and obstetric factors related to those evaluated.

\section{Methodology}

A Cross-sectional study with a quantitative, descriptive and analytical approach (Pereira et al., 2018), carried out in the public maternity hospital in the municipality of Lagarto (SE), called the Association for Assistance and Protection of Maternity and Childhood, known as Maternity Zacarias Júnior, is a reference center for the municipality of Lagarto-Sergipe and the central-south region of Sergipe and northern Bahia, where the study was carried out, has the title of Hospital Amigo da Criança by the Ministry of Health.

The study included 1.149 postpartum women in the immediate period aged between 13 and 45 years. The study presents a convenience sample in which participants were recruited between November 2016 and December 2019. Twentyfour evaluation forms were excluded, whose data from the puerperal women were incomplete or illegible, leaving 1.125 forms for analysis.

The study was approved by the Ethics Committee for Research with Human Beings at UFS (CAAE 61988416.0.0000.5546). All participants agreed to participate in the research and signed the Informed Consent Form (FIC) before the initial assessments. Patients under the age of 18 years were evaluated upon release of their guardian. The participants had their identity preserved and, at the time of evaluation, they received treatment and/or guidance according to their need at the time.

Data were collected at the bedside at the Zacarias Júnior Maternity Hospital, Lagarto. The sample was characterized by the collection of the following data: age of the mothers, life habits (sedentary lifestyle/smoking/alcoholism); marital status (single, married, stable, unregistered); educational level. In the obstetric history, prenatal care was evaluated (whether it was performed or not and the number of consultations); the number of abortions, births and pregnancies; gestational age; parity; types of delivery (cesarean or vaginal); complications and cephalopelvic disproportion (CPD). In the Analysis of the obstetric history, the presence of trauma to the pelvic floor (episiotomy/ laceration) was investigated; pain (intensity and location); difficulty breastfeeding; voiding disorders; constipation.

Statistical analyzes were performed using the SPSS program (SPSS for Windows - Version 20.0 - SPSS Inc.) and the significance level was adjusted to $5 \%(\mathrm{p} \leq 0.05)$. Descriptive analysis was performed to obtain the frequencies and percentages to describe the population analyzed. To obtain the odds ratio (OR) and the $95 \%$ confidence interval (CI), binary logistic regression was performed considering the mode of delivery (cesarean or vaginal) as the dependent variable. The independent variables were separated into blocks considering the social profile and obstetric history. The results were analyzed considering the most frequent category for the type of delivery variable. 


\section{Results}

The sample consisted mostly of women aged 18 years or over (mean age 25.70, ranging from 13 to 45 years old); married $(n=492)$ and with elementary school $(n=208)$ and high school $(n=185)$. Regarding the mode of delivery, 578 puerperal women were vaginally and 565 by cesarean, most of them primiparous $(n=532)$. Logistic regression showed that level of elementary education is related to a higher probability of delivery via cesarean OR, 2.99; 95\%CI, 1.403-6.411); just as married marital status is related to vaginal (OR, 10.463; 95\%CI, 2.367-46.254). There was no significant influence of the puerperal women's age and lifestyle in defining the mode of delivery. Data on social characterization and lifestyle habits are shown in Table 1.

Table 1. Distribution of mothers attended at the Zacarias Júnior Maternity Hospital according to their social characteristics and lifestyle habits - Lagarto-SE, 2016-2019.

\begin{tabular}{|c|c|c|c|c|c|}
\hline Variable $(n=1.119)$ & $\begin{array}{c}\text { Caesarean } \\
n(\%) \\
\end{array}$ & $\begin{array}{c}\text { Vaginal } \\
n(\%)\end{array}$ & p-value & O.R & CI \\
\hline \multicolumn{6}{|l|}{ Age (years) } \\
\hline$<18$ & $57(10.3)$ & $62(10.9)$ & 0.784 & & \\
\hline$\geq 18$ & $494(89.7)$ & $506(89.1)$ & 0.757 & & \\
\hline \multicolumn{6}{|l|}{ Education (years of study) } \\
\hline Illiterate & $14(3.8)$ & $1(0.8)$ & 0.507 & & \\
\hline Elementary & $131(35.6)$ & $77(63.1)$ & $0.05^{*}$ & 2.999 & $1.403-6.411$ \\
\hline High & $152(41.3)$ & $33(27.0)$ & 0.828 & & \\
\hline College & $71(19.3)$ & $11(9.0)$ & 0.507 & & \\
\hline \multicolumn{6}{|l|}{ Marital status } \\
\hline Married & $205(43.9)$ & $286(68.6)$ & $0.02 *$ & 10.463 & $2.367-46.254$ \\
\hline Single & $247(52.9)$ & $129(30.9)$ & 0.73 & & \\
\hline No registry & $15(3.2)$ & $2(0.5)$ & 0.73 & & \\
\hline \multicolumn{6}{|l|}{ Living Habits } \\
\hline \multicolumn{6}{|l|}{ Sedentary lifestyle } \\
\hline Yes & $212(48.2)$ & $190(44.1)$ & 0.225 & & \\
\hline No & $228(51.8)$ & $241(55.9)$ & & & \\
\hline \multicolumn{6}{|l|}{ Smoking } \\
\hline Yes & $20(3.9)$ & $20(3.9)$ & 0.975 & & \\
\hline No & $492(96.1)$ & $497(96.1)$ & & & \\
\hline
\end{tabular}

*Significant values $(\mathrm{p}<0.05)$ using binary logistic regression.

Fonte: Autores.

The results of the obstetric history show that women with a greater chance of having a vaginal birth were multipregnancy (OR, 9.54; 95\% CI, 7.19-12.65) and multiparous (OR, 8.79; 95\%CI, 6.66-11.62); performed prenatal care, from one to seven consultations (OR, 1.534; 95\%CI, 1.18-1.98); and belong to the group that does not have comorbidities (OR,1.69, 95\%CI, 1.23-2.28), as described in Table 2. As for pain, postpartum women who had a vaginal birth are more likely to report no pain $(\mathrm{OR}, 2.08 ; 95 \% \mathrm{CI}, 1.63-2.65)$ and greater difficulty in breastfeeding (OR, 1.373, 95\%CI, 1.04-1.80) when compared to cesarean section. Constipation and voiding disorders had no significant association with the mode of delivery. Obstetric history, pain and breastfeeding data are shown in Table 3. 
Table 2. Characterization of the history and obstetric characteristics of the mothers attended at the Zacarias Júnior Maternity Hospital - Lagarto-SE, 2016-2019.

\begin{tabular}{|c|c|c|c|c|c|c|}
\hline Variable $(n=x x)$ & $\begin{array}{c}\text { Caesarean } \\
n(\%)\end{array}$ & $\begin{array}{c}\text { Vaginal } \\
n(\%)\end{array}$ & p-value & O.R & & CI $95 \%$ \\
\hline \multicolumn{7}{|l|}{ Number of pregnancies } \\
\hline Primary & $391(69.3)$ & $100(19.2)$ & 0.00 & 0.105 & 0.79 & 0.139 \\
\hline Multiple & $173(30.7)$ & $422(80.8)$ & 0.00 & 9.538 & 7.194 & 12.645 \\
\hline \multicolumn{7}{|l|}{ Number of deliveries } \\
\hline Primary & $414(73.4)$ & $118(23.9)$ & 0.00 & 0.114 & 0.086 & 0.150 \\
\hline Multiple & $150(26.6)$ & $376(76.1)$ & 0.00 & 8.795 & 6.656 & 11.621 \\
\hline \multicolumn{7}{|l|}{ Number of abortions } \\
\hline Yes & $91(17.7)$ & $76(14.0)$ & 0.09 & & & \\
\hline No & $423(82.3)$ & $467(86.0)$ & & & & \\
\hline \multicolumn{7}{|l|}{$\begin{array}{l}\text { No. of prenatal } \\
\text { consultations }\end{array}$} \\
\hline None & $1(0.3)$ & $1(0.2)$ & 0.92 & & & \\
\hline 1 a 7 & $183(52.3)$ & $247(51.2)$ & 0.00 & 1.534 & 1.183 & 1.989 \\
\hline 8 or more & $166(47.4)$ & $234(48.5)$ & 1.00 & & & \\
\hline \multicolumn{7}{|l|}{ Comorbidities } \\
\hline Yes & $237(65.5)$ & $188(52.8)$ & 0.01 & 0.59 & 0.437 & 0.797 \\
\hline No & $125(34.5)$ & $168(47.2)$ & 0.01 & 1.694 & 1.255 & 2.288 \\
\hline
\end{tabular}

*Significant values $(\mathrm{p}<0.05)$ using binary logistic regression.

Fonte: Autores.

Table 3. Characterization of immediate puerperal complaints of patients evaluated at the Zacarias Júnior Maternity Hospital Lagarto-SE, 2016-2019.

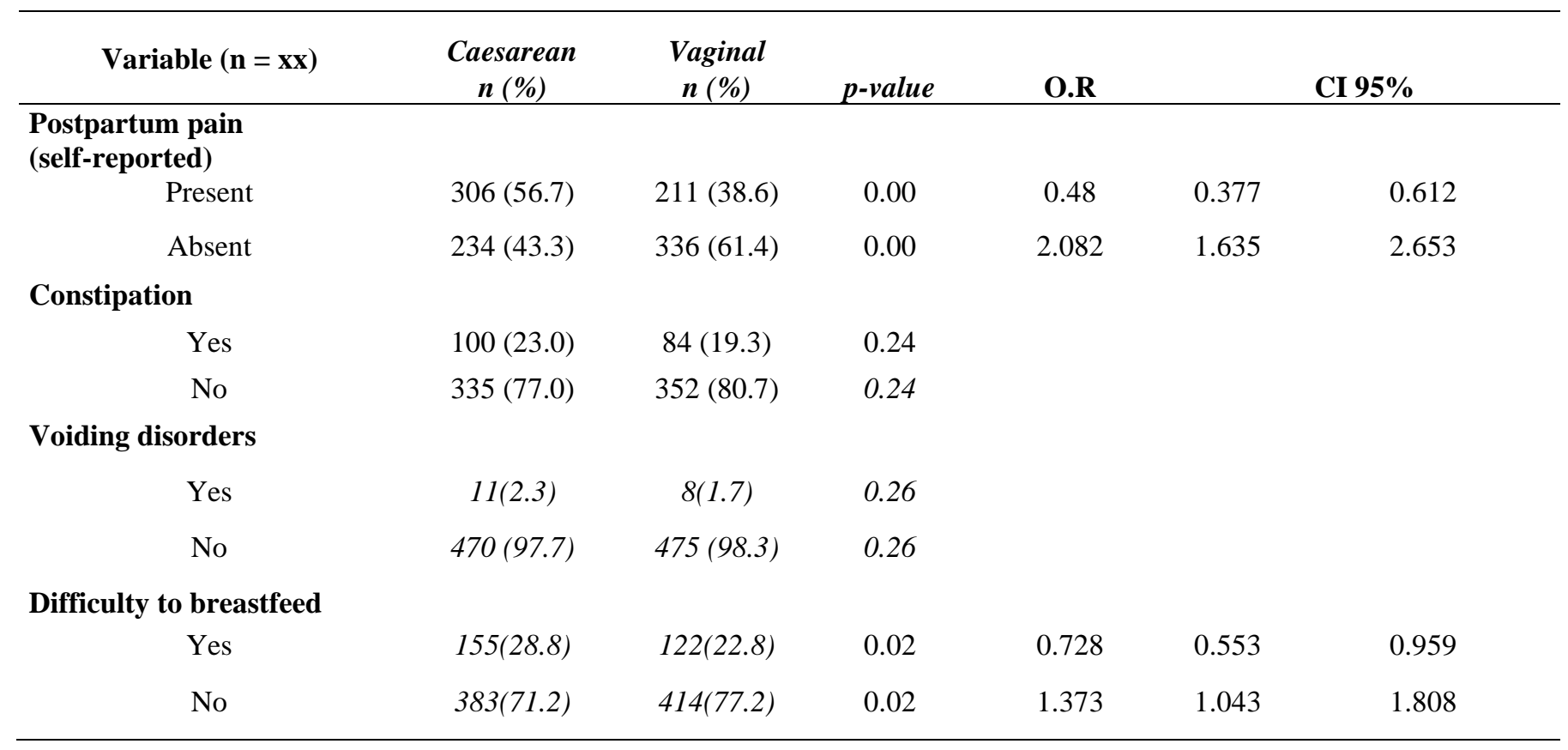

*Significant values $(\mathrm{p}<0.05)$ using binary logistic regression.

Fonte: Autores. 
The result of the analysis indicates that primiparous women undergoing cesarean section is more likely to have had no abortion in their previous history (OR, 1.69; 95\%CI, 1.192-2.415) compared to multiparous women. The data for this distribution are shown in Table 4.

Table 4. Binary Logistic Regression Analysis considering the chances of women with Cesarean delivery having had an abortion in their obstetric history.

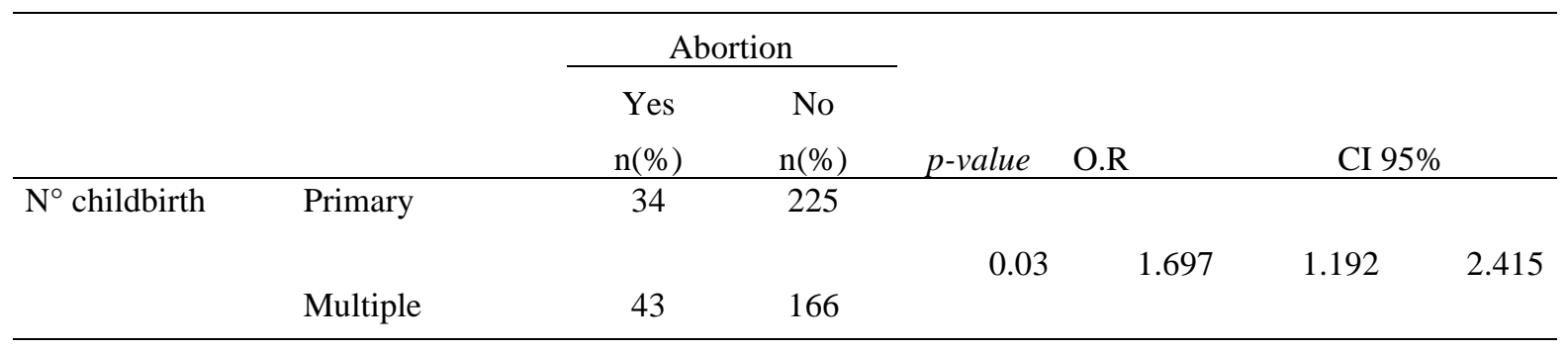

*Significant values $(\mathrm{p}<0.05)$ using binary logistic regression.

Fonte: Autores.

\section{Discussion}

Our study observed a higher prevalence of cesarean deliveries, which corroborates previous studies that compared international and national contexts. (Boerma et al., 2018; Eufrasio et al., 2018; Leal et al., 2014; MS, 2016; Rebelo et al., 2010). Fernandes et al., 2019 observed that the choice of the route of delivery for high-risk pregnant women followed up in specialized public outpatient clinics, is characterized by a divergence between the maternal and medical decision, putting the co-management of care at risk. According to Leal et al., 2014 and Eufrázio et al., 2018 there is a low rate of good practices, with unnecessary interventions during labor. These factors, associated, may explain the high rates of cesarean delivery, exceeding the percentage of 25-30\% recommended for Brazil (MS, 2016) even in women assisted in maternity hospitals with a low obstetric risk profile (Boerma et al., 2018; Eufrasio et al., 2018; Leal et al., 2014). Higher rates of cesarean delivery are related to higher postpartum and newborn mortality (Victoria et al., 2011).

The multifactorial nature of this reality transcends structural or assistance issues. The maternity hospital where this study was carried out is of low risk, has a structure for humanized childbirth, has obstetric nurses in obstetric centers and provides non-pharmacological resources for pain relief during labor. Social factors such as education and health awareness likely interfere in the conduct of childbirth and puerperium. Concerning education, we found a positive association only with primary education and cesarean delivery.

Previous studies have shown that cesarean deliveries have greater associations (Eufrasio et al., 2018; Leal et al., 2014; Mendoza-Sassi, 2010; Rasador \&Abegg, 2019) and prevalence (Boerma et al., 2018; Faisal-Cury et al., 2017; Rattner \& Moura, 2016) in postpartum women with a higher level of education. A study conducted by Eufrásio et al., 2018 showed that the higher level of education of the postpartum women may be associated with a higher level of information about their health status, greater access to health facilities, prenatal consultations, greater power choice about the mode of delivery and consequently reduced gestational complications. In addition, the choice of the cesarean section may be related to medical advice, poor previous experience with vaginal birth, fear of pain during labor and the perception of greater damage to the pelvic floor (with risk of urinary incontinence or sexual difficulty) (Eufrásio et al., 2018).

Another aspect of the level of education and type of delivery method refers to the number of prenatal consultations, especially when it is observed that education less than 8 years may be related to the lower number of prenatal consultations (Domingues et al., 2016). In our study, pregnant women who had up to 7 prenatal consultations were associated with vaginal delivery, corroborating Gama et al., 2014 by observing that the greater the number of medical care during prenatal care, the 
greater be the choice induced by cesarean section. A maioria das puérperas deste estudo tiveram acompanhamento pré-natal com número de consultas adequadas, resultado encontrado nos estudos de Domingues et al. 2016, Eufrásio et al. 2018 e Ferrari et al., 2016.

A point of conflict between factors associated with the mode of delivery refers to maternal marital status and maternal age. Although some studies deny the association of marital status with the vaginal route (Faisal-Cury et al., 2017; Rattner \& Moura, 2016) and age (Moreira et al., 2016; Oliveira et al., 2016; Rasador \& Abegg, 2019); others find that married women (Mendoza-Sassi et al., 2010; Pádua et al., 2010) and older (Eufrasio et al., 2018; Fasial-Cury et al., 2017; Guimarães et al., 2017; MS, 2016; Rattner \& Moura, 2016) have more cesarean deliveries. Our results showed a positive association between married women and vaginal delivery, with no relationship with the age factor being found.

Vaginal delivery was also associated with multipregnancy and multiparous women, in agreement with the literature (Boerma et al., 2018; Guimarães et al., 2017; Leal et al., 2014). Moreira et al., 2016 observed in a sample of 82 women, that 50 underwent cesarean delivery. They were not primigravid and were younger than 35 years old. In the profile of postpartum women in our study, most primiparous postpartum women underwent cesarean delivery, when compared to the vaginal route. Reality is also verified by the studies by Rebelo et al., 2010, Domingues et al. 2016 and Ferrari et al. 2016. The high prevalence of cesarean in primiparous women is related to a greater number of complications and worse maternal and child clinical outcomes (Boerma et al., 2018; Domingues et al., 2016; Moreira et al., 2016; Oliveira et al., 2016; Pádua et al., 2010).

The results confirmed the association between the absence of maternal comorbidity and vaginal deliveries. There is scientific evidence that pregnant women with hypertensive syndromes are 2.77 times more likely to undergo cesarean delivery (Eufrasio et al., 2018). The prevalence of cesarean sections in pregnant women with hypertensive syndromes can reach up to 45\% (Rasador \& Abegg, 2019).

It is noteworthy that most of the sample was non-smokers and non-sedentary, demonstrating healthy lifestyle behaviors that were not related to the mode of delivery. The study by Oliveira et al, 2016 observed an association between gestational obesity and cesarean section. It is known that lifestyle, such as the practice of light to moderate physical activity, during pregnancy contributes to maternal and fetal well-being and reduces the risk of hypertensive syndromes (Davenport et al., 2018).

In this study, puerperal women who underwent cesarean delivery reported more complaints of pain and difficulty in breastfeeding when compared to those who underwent vaginal delivery. Santos et al., 2016 and Santos et al, 2016 also observed that pain is more present in postpartum women after cesarean delivery. Pain restricts mobility, self-care and transfers. These limitations are barriers to breastfeeding and can influence the maternal bond with the newborn (Santos et al., 2016 and Santos et al, 2016).

There was no significant association of constipation and voiding disorders with the mode of delivery. MartínezGaliano et al., 2019 (Martinez-Galiano et al., 2019) highlight that instrumental birth compared to vaginal birth is a risk factor in the puerperium for constipation and urinary incontinence.

In our study, the highest frequency of abortion was found in the obstetric history of women undergoing cesarean section and multiparous. According to Victora et al., 2011 unsafe abortion is a challenge to assess mortality, being an important cause of maternal morbidity. The knowledge of the real rates of hemorrhage, infections, infertility and mental illnesses related to women who cause abortions are hampered by the imprecision of the data and the methodological weakness of the studies.

It is suggested to continue this research, to longitudinally assess postpartum women, expanding the number of women evaluated, using complementary records for better clinical and functional analyzes during pregnancy, childbirth and immediate and late puerperium. 


\section{Conclusion}

The present study carried out in a public maternity hospital, a regional reference in the State of Sergipe, allowed the identification of the profile of immediate mothers, mostly primiparous, young, married and educated at the primary level. The number of women undergoing cesarean delivery was high, with a significant association of this route with primary education and puerperal complaints such as pain and difficulty to breastfeed. The postpartum women who underwent vaginal delivery had an obstetric history of multiparity and absence of comorbidities.

The effectiveness of education and health as well as interdisciplinary intervention, including physical therapy assistance, based on scientific evidence can contribute to the management of pregnancy and childbirth, resulting in a better immediate puerperal state.

The study has some limitations that shoul be evaluated in future research with as cultural, financial and technical/care factors were not investigated, which include medical performance and perception, anesthetic scale and logistics of patient care.

\section{Acknowledgments}

Zacarias Junior Maternity

UFS Lagarto

EMPLOYEES - ICMJE

\section{References}

Ministério da Saúde (2019). Saúde da mulher na gestação, parto e puerpério. Nota técnica para organização da rede de atenção à saúde com foco na atenção primária à saúde e na atenção ambulatorial especializada. Departamento de atenção básica: Ministério da Saúde.

Moreira, B. R., Carvalho, P. L., Dutra, J. P., Coelho, P. B., Rocha, R. L., \& Rocha, A. L. (2016). Determinantes relacionados ao parto cesáreo em maternidade pública da Região Metropolitana de Belo Horizonte-MG. Rev Med Minas Gerai, 26, 1799. http://dx.doi.org/10.5935/2238-3182.20160099

Lotfi, R., Tehrani, F. R., Dovom, M.R., Torkestani, F., Abedini, M., \& Sajedinead, S. Development of strategies to reduce cesarean delivery rates in Iran 20122014: a mixed methods study. (2014). Int J Prev Med, 5,1552-66.

Andrade, R. D., Santos, J. S., Maia, M. A. C., \& Mello, D. F. Fatores relacionados à saúde da mulher no puerpério e repercussões na saúde da criança. (2015). Esc Anna Nery, 19, 181-186. https://doi.org/10.5935/1414-8145.20150025

Baratieri, T., \& Natal S. Ações do programa de puerpério na atenção primária: uma revisão integrativa. (2019). Ciência \& Saúde Coletiva, 24, 4227-4238. https://doi.org/10.1590/1413-812320182411.28112017

Ministério da Saúde (BR). (2011). Portaria n. 1.459, de 24 de junho de 2011. Institui, no âmbito do sistema único de saúde- SUS, a Rede Cegonha. MS. [Internet].

Pereira, T. R. C., Montesano, F. T., Ferreira, P. D., Minozzi, A. S., \& Beleza, A. C. S. (2017). Existe associação entre os desconfortos no puerpério imediato e a via de parto? Um estudo observacional, ABCS Health Sci, 42, 80-84. http://dx.doi.org/10.7322/abcshs.v42i2.1007

Burti, J. S., Cruz, J. P. S., Silva, A. C., \& Moreira, I. de L. (2016). Assistência ao puerpério imediato: o papel da fisioterapia. Rev Fac Ciênc Méd Sorocaba, 18,193-8. https://doi.org/10.5327/Z1984-4840201625440

Mazzoni, A., Althabe, F., Liu, N. H., Bonotti, A. M., Gibbons, L., Sánchez, A. J., Belizán, J. M. e t al. (2011). Women's preference for caesarean section: a systematic review and meta-analysis of observational studies. BJOG, 118, 391-399. http://dx.doi:10.1111/j.1471-0528.2010.02793

Pereira, A. S. et al. (2018). Metodologia da pesquisa cientifica. UFSM. https://repositorio.ufsm.br/bitstream/handle/1/15824/Lic_Computacao_MetodologiaPesquisa-Cientifica.pdf?sequence $=1$.

Ministério da Saúde. (2016). Diretrizes de atenção à gestante: a operação cesariana. Secretaria de Ciência, Tecnologia e Insumos Estratégicos: Ministério da Saúde.

Rebelo, F., Rocha, C. M. M., Cortes, T. R., Dutra, C. L., \& Kac, G. (2010). High cesarean prevalence in a national popula $\neg$ tion-based study in Brazil: the role of private practice. Acta Obstet Gynecol Scand, 89, 903-8. https://doi.org/10.3109/00016349.2010.484044

Leal, M. C., Pereira, A. P. E., Domingues, R. M. S. D., Theme Filha, M. M., Dias, M. A. B., Nakamura-Pereira, M., Bastos, M. H., \& Gama, S. G. N. (2014). Intervenções obstétricas durante o trabalho de parto e parto em mulheres brasileiras de risco habitual. Cad Saúde Pública, 30, 17-47. https://doi.org/10.1590/0102-311X00151513 
Boerma, T., Ronsmans, C., Melesse, D. Y., Barros, A. J. D., Barros, F. C., Juan, L., Moller, A. B., Say, L., Hosseinpoor, A. R., Yi, M., Neto, D. L. R., \& Temmerman, M. (2018). Global epidemiology of use of and disparities in caesarean sections, Lancet 392,(10155),1341-1348. http://doi.org/10.1016/S0140$6736(18) 319287$

Eufrásio, L. S., Souza, D. E., Fonsêca, A. M. C., Viana, E. S. R. (2018). Diferenças regionais brasileiras e fatores associados à prevalência de cesárea, Fisioter. Mov. 31003108. http://dx.doi.org/10.1590/1980-5918.031.AO08

Fernandes, J. A., Campos, G. W. S., \& Francisco, P. M. S. B. (2019). Perfil das gestantes de alto risco e a cogestão da decisão sobre a via de parto entre médico e gestante. Saúde em Debate, 43, 406-416. https://dx.doi.org/10.1590/0103-1104201912109

Victora, C. G., Aquino, Leal, E. M., M. C., Monteiro, C. A., Barros, F. C., \& Szwarcwald, C. L. (2011). Maternal and child health in Brazil: progress and challenges. The Lancet, 377, 1863-1876. https://dx.doi:10.1016/s0140-6736(11)60138

Rasador, S., \& Abegg C. (2019). Fatores associados à via de parto em um município da região nordeste do Estado do Rio Grande do Sul, Brasil. Revista Brasileira de Saúde Materno Infantil, 19(4), 797-815. 10.1590/1806-93042019000400004.

Mendoza-Sassi, R. A., Cesar, J. A., Silva, P. R., Denardin, G., \& Rodrigues, M. M. (2010). Risk factors for cesarean section by category of health servisse. Rev Saude Publica, 44, 80-89. https://dx.doi.org/10.1590/S0034-89102010000100009

Faisal-Cury, A., Menezes, P. R., Quayle, J., Santiago, K., \& Matijasevich, A. (2017). The relationship between indicators of socioeconomic status and cesarean section in public hospitals. Rev Saude Public. 51. https://dx.doi.org/10.1590/S1518-8787.2017051006134

Rattner, D., \& Moura, E. C. de. (2016). Nascimentos no Brasil: Associação do tipo de parto com variáveis temporais e sociodemográficas. Revista Brasileira de Saúde Materno Infantil, 16(1), 39-47. 10.1590/1806-93042016000100005

Domingues, R. M. S. M., Dias, M. A. B., Schilithz, A. O. C., \& Leal, M. C. (2016). Factors associated with maternal near miss in childbirth and the postpartum period: findings from the birth in Brazil National Survey, 2011-2012. Reproductive Health, 13, 115. http://dx.doi.org/10.1186/s12978-016-0232-y

Gama, S. G. N., Viellas, E. F., Schilithz, A. O. C., Filha, M. M. T., Mariza, C. M. L., Gomes, K. R. O., Costa, M. C. O., \& Leal, M. C. (2014). Fatores associados à cesariana entre primíparas adolescentes no Brasil, 2011-2012. Cadernos de Saúde Pública, 30, S117-S127. https://dx.doi.org/10.1590/0102$311 \mathrm{X} 00145513$

Ferrari, A. P., M. Carvalhaes, A. B. L., \& Parada, C. M. G. L. (2016). Associação entre pré-natal e parto na rede de saúde suplementar e cesárea eletiva. Revista Brasileira de Epidemiologia, 19, 75-88. https://dx.doi.org/10.1590/1980-5497201600010007

Guimarães, M. R., Silva, R. L. P. D., Dutra, V. G. P., Andrade, P. G. P., Ana Camila, R., Jomar, R. T., \& Freire, R. P. (2017). Fatores associados ao tipo de parto em hospitais públicos e privados no Brasil. Revista Brasileira de Saúde Materno Infantil, 17, 571-580. https://dx.doi.org/10.1590/180693042017000300009

Oliveira, R. R. de, Melo, E. C., Novaes, E. S., Ferracioli, P. L. R. V., \& Mathias, T. A. F. (2016). Fatores associados ao parto cesárea nos sistemas público e privado de atenção à saúde. Revista da Escola de Enfermagem da USP, 50(5), 733-740. http://dx.doi.org/10.1590/S0080-623420160000600004

Pádua, K. S., Osis, M. J. D., Faúndes, A., Barbosa, A. H., \& Moraes Filho, O. B. (2010). Fatores associados à realização de cesariana em hospitais brasileiros. Rev Saúde Pública, 44, 70- 9. https://dx.doi.org/10.1590/S0034-89102010000100008

Davenport, M. H., Ruchat, S. M., Poitras, V. J., Jaramillo, G. A., Gray, C. E., Barrowman, N., Skow, R. J., Meah, V. L., Riske, L., Sobierajski, F., James, M., Kathol, Nuspl, A. J., M., Marchand, A. A., Nagpal, T. S., Slater, L. G., Weeks, A., Adamo, K. B., Davies, G. A., Barakat, R., \& Mottola, M. F. (2018). Prenatal exercise for the prevention of gestational diabetes mellitus and hypertensive disorders of pregnancy: a systematic review and meta-analysis. $B r J$ Sports Med, 52, 1367-7.

Santos, J.O., Pacheco, T.S., Oliveira, P.S., Hino, P., \& Barbieri, M. C. M, (2016). Avaliação da dor no período puerperal: estudo comparativo entre os tipos de parto. J Health Sci Inst, 34, 200-5. https://dx.doi:10.5585/ConsSaude.v15n4.6672

Santos, P. L., Rett, M. T., Lotti, R. C. B., Moccellin, A. S., \& DeSantana, J. M. A. (2016). Via de parto interfere nas atividades cotidianas no puerpério imediato? Conscientiae Saúde, 15, 604-611.

Martínez-Galiano, J. M., Delgado-Rodríguez, M., Rodríguez-Almagro, J., \& Hernández-Martínez, A. (2019). Symptoms of Discomfort and Problems Associated with Mode of Delivery During the Puerperium: An Observational Study. International Journal of Environmental Research and Public Health., 16, 4564. https://dx.doi.org/10.3390/ijerph16224564 